\title{
Editorial 2017/XII/1
}

\section{Jana Dlouhá}

Envigogika 12 (1) - Úvodník / Editorial

Publikováno/Published dne 26. 10. 2017

DOI: $\underline{10.14712 / 18023061.550}$

Vážení čtenáři,

přinášíme vám nové číslo Envigogiky - přehledně: 6 článků, $z$ toho $2 / 3$ recenzovaných, celkem 103 stran textu, počíáme-li ovšem 37 stránek inspirativní povahy. Sešlo se zde 10 autorů, z toho jen 3 muži. První letošní číslo je zároveň 32. vydáním časopisu, který vychází již 12. rokem - přehled toho, co jsme dosud vydali, viz tabulka 1.

Dozvěděli jste se z tohoto výčtu něco podstatného o povaze, nebo kvalitě textů, a o Envigogice jako takové? Informace tohoto typu vedou asi jen $\mathrm{k}$ úvahám o mase slov a písmen, které byly určitým způsobem kultivovány - posouzeny recenzenty, zpracovány editory, formálně ošetřeny. O povaze výsledku ale nesvědčí. Tato exaktní data můžeme použivat nanejvýš $v$ symbolické rovině, např́iklad přemýšlet o magii čísel $1,2,3$, která se zde opakují $v$ různých kombinacích, součtech, násobcích... Na jejich základě Ize rozvíjet úvahy veskrze osudové, jež ovšem nevybízejí k další debatě, výměně zkušeností, usilování o změnu. Nepřitahují pravděpodobně ani pozornost čtenářů.

O to nám ale právě jde - být prostředníkem mezi těmi, kteří mohou a mají potřebu cosi sdělit, a poněkud anonymním, avšak pozorným a naslouchajícím obecenstvem. $Z$ tohoto hlediska je ve zvyku uvádět údaje o čtenosti a citovanosti textů: jejich celkový „impakt". Mají ukazovat obecně uznávanou "cenu" publikovaných článků i celkovou "hodnotu" časopisu, jež pak je přitažlivý především pro autory. „Impaktový" status publikačního média přebírají jednotlivé př́spěvky; časopis se pak stává i žádoucím zdrojem informací hlavně zase pro ty, kdo zde chtějí publikovat. Smyslem je podpořit publikační procesy, jakožto ovšem soutěž autorů a o autory, do níž jsou zahrnuti aktivní (tedy citující) čtenáři jako rukojmí. Protože - co my všichni ostatní? Psát, aby (člověk, autor) zvítězil, je těžké; číst, aby se podpořilo vítězství někoho jiného (většinou na oplátku), ještě těžší. Dává to smysl jen za určitých okolností: publikační dostihy fungují, pokud se vytvoří dostatečně soudržné společenství lidí, kteří si vzájemně naslouchají a podporují se. A to je právě naším cílem. Abychom si v tomto ohledu rozuměli: Envigogika sdružuje 262 autorů, 212 recenzentů, 2 a více editorů, a množství čtenářů, kteří ji denně navštěvují (314 registrovaných, další viz obr. 1.). Důležité ale je, zda si máme pořád co říci.

V tomto čísle Envigogiky se o to pokoušejí (výše zmínění) autoři. Zuzana Svobodová uvažuje o prírozenosti, jež je základem výchovy, ale také jedním z "protikladư" kultivace 
člověka. Je podmínkou harmonického života utvářeného výchovným působením - a to podmínkou, která má být příhodně využita ve vhodné (naší?) době. Renomovaný kolektiv autorů (Svatava Janoušková, Tomáš Hák, Bedřich Moldan) přemýšlí o indikátorech udržitelného rozvoje jako o nástrojích pro vzdělávání veřejnosti. Navrhuje pět klíčových indikátorů - lidé, planeta, prosperita, mír a partnerství - které reprezentují hlavní dimenze udržitelnosti, a tedy zpřehledňuji tuto poněkud složitou oblast. Jsou tak nástroji osvěty, mohly by ale také sloužit jako velmi obecné vzdělávací cíle, jež Ize pro různé potřeby a úrovně vzdělání naplnit konkrétním obsahem. Silvie Svobodová zjištuje vliv vybraných proměnných na environmentální gramotnost žáků 2 . stupně základní školy: analyzuje především působení volnočasových aktivit na hodnoty environmentálních vědomostí a proenvironmentálních postojů (nejpříznivěji se projevují aktivity zaměřené na pobyt $v$ př́rodě a sport).Danuše Strnadová, Hana Brůhová Foltýnová a Radomíra Jordová hodnotí výsledky dopravní kampaně „Oblékáme hada Edu” určené pro děti z mateřských škol a 1. stupně základních škol. Jak vyplývá z dat shromažd'ovaných od roku 2014 ve 49 školách, mezi hlavní faktory úspěchu patř́i... ale to už se dočtete v samotném článku.

V textu, který by nás měl inspirovat, uvažuje Jiří Olšovský na téma souznění, autentického spojenectví člověka s prírodou, s mimolidskými bytostmi, s celkem bytí a kosmu. (Potřebnou) změnu myšlení staví do opozice proti vyumělkovaným spekulacím a zlovolným konstrukcím dneška. $V$ jiném textu, sestaveném na základě výpovědí drobných podnikatelů, hledá i další z autorů (Jana Dlouhá) nový, ,autentický“ vztah k původním zdrojům, postupưm, procesům a jejich výsledkům, a tedy ke skutečnosti jako takové. Ukazuje se, že práce pomáhá člověku si uvědomit sebe sama, hledat své místo $v$ širším společenství i okolním prostředí, rozvíjet své vztahy $\mathrm{k}$ jiným lidem i chápat smysl své každodenní existence. Zkušenosti úspěšných, byt' $v$ našich podmínkách těžce se prosazujících podnikatelů, shromážděné $v$ tomto textu a transformované do podoby etických principů a základních kompetencí nezbytných pro zelené podnikání, Ize pak také využít jako základ výchovy k (poctivému) občanství, která v našich podmínkách citelně chybí.

Přejeme i Vám, aby se dařilo (třebaže těžce) se probíjet $k$ vlastní, autentické zkušenosti a tedy i poznání. Snad k tomu i toto číslo Envigogiky tak trochu přispělo.

Tabulka 1. počet článků v Envigogice od r. 2006

\begin{tabular}{|c|c|c|c|c|c|c|c|c|c|}
\hline & $\begin{array}{c}\text { Články } \\
\text { (Jrec) a } \\
\text { metodiky }\end{array}$ & $\begin{array}{c}\text { Př́padové } \\
\text { studie }\end{array}$ & Inspirace & Recenze & Informace & $\begin{array}{c}\text { Dopisy } \\
\text { názory } \\
\text { nautory }\end{array}$ & $\begin{array}{c}\text { Pro } \\
\text { auodník }\end{array}$ & Celkem \\
\hline $\begin{array}{c}2006 \\
2017\end{array}$ & 142 & 3 & 113 & 59 & 56 & 21 & 6 & 32 & 432 \\
\hline
\end{tabular}




\section{Obr. 1. Návštěvnost Envigogiky v posledním období}

Envigogika

Všechny údaje o webu

Prehled publika

$$
\begin{aligned}
& \text { Všichni uživatelé } \\
& 100,00 \% \text { Nãvs̆těvy }
\end{aligned}
$$

Přehled

\section{- Návštěry}

60
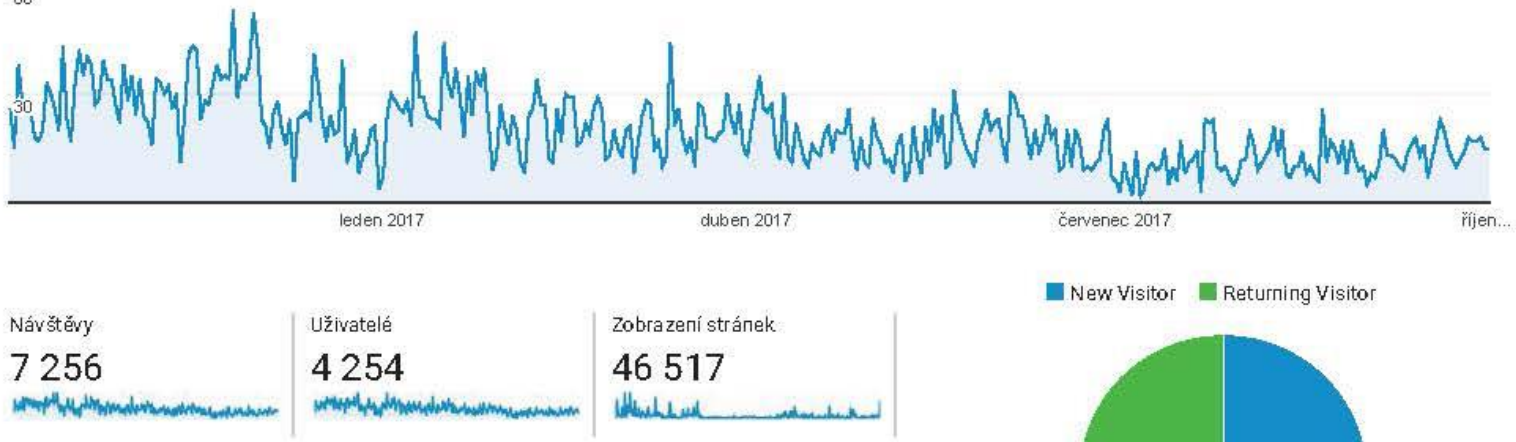

Zobrazení stránek

\section{7}

Počet stránek na 1 návštěvu

\section{6,41}

Prủm. doba trváni návštěvy 00:02:40
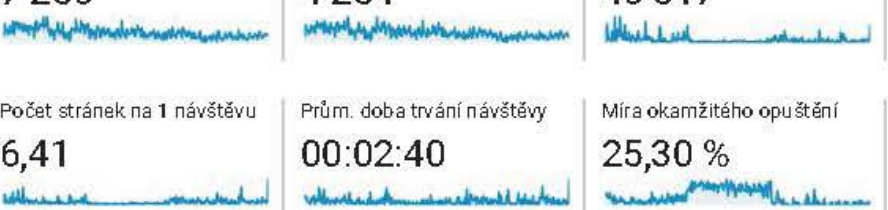

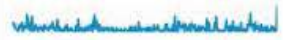

Míra okamžitého opuštění $25,30 \%$

New Visitor Returning Visitor

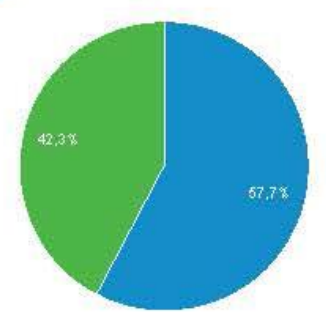

\% nových návštěv

$57,70 \%$ 